\title{
PENGARUH KARAKTERISTIK PENYULUH, KONDISI KERJA, MOTIVASI TERHADAP KINERJA PENYULUH PERTANIAN DAN PADA PERILAKU PETANI PADI DI KABUPATEN REMBANG
}

(The Effect Of Extention Agents Characteristics, Working Conditions, Motivation Forward Performance of Agricultural Extention And The Behavior of Rice Farmer In Rembang Regency)

\author{
S. Arifianto ${ }^{1}$, S. Satmoko ${ }^{2}$ dan B. M. Setiawan ${ }^{3}$ \\ ${ }^{1}$ Dinas Pertanian dan Pangan Kabupaten Rembang \\ ${ }^{2,3}$ Fakultas Peternakan dan Pertanian Universitas Diponegoro \\ Email: siswonoarifianto@rembangkab.go.id \\ Diterima 22 Agustus 2017, disetujui 5 November 2017
}

\begin{abstract}
ABSTRAK
Tujuan penelitian adalah menganalisis pengaruh karateristik penyuluh, kondisi kerja dan motivasi terhadap kinerja penyuluh pertanian dan pengaruhnya terhadap perilaku petani di Kabupaten Rembang. Penelitian dilakukan di Kabupaten Rembang dan merupakan penelitian kuantitatif analitik. Responden penelitian sebanyak 136 orang penyuluh pertanian atau seluruh populasi, kemudian untuk mengetahui out put kinerja penyuluh pertanian yaitu perilaku petani, dibutuhkan responden petani sebesar 272 orang yang merupakan petani binaan penyuluh pertanian yang dipilih secara acak, tersebar pada 14 kecamatan di Kabupaten Rembang. Pengambilan data menggunakan kuesioner dan dianalisis menggunakan Struktural Equation Model (SEM) dengan program Amos. Hasil penelitian menunjukkan bahwa karateristik penyuluh, kondisi kerja dan motivasi berpengaruh positif terhadap kinerja penyuluh pertanian, dan kinerja penyuluh pertanian berpengaruh terhadap perilaku petani di Kabupaten Rembang. Jadi karakteristik, motivasi dan kondisi kerja berperan penting dalam peningkatan kinerja penyuluh pertanian sehingga berdampak pada perilaku petani, Oleh karena itu saran yang diajukan adalah agar para penyuluh pertanian diharapkan dapat meningkatkan kapasitasnya melalui pendidikan jenjang lebih tinggi, pelatihan.
\end{abstract}

Kata kunci: kinerja, motivasi, penyuluh, perilaku dan pertanian.

\section{ABSTRACT}

The purposes of this study were to analyze the influence of agricultural extension agent's characteristic, working conditions and motivation on the agricultural extension agent's performance and its impact on farmer's behavior in Rembang. The research conducted in Rembang Regency. Quantitative analytic research was used in the research. 136 Agricultural extension agents were interviewed, followed then 272 farmer were interviewed to exlore the farmers' behavior as an output performance by random sampling method. Data were collected using questionnaires. Data were analyzed with Structural Equation Model (SEM) using Amos program. The results showed that Agricultural extension agent's characteristics, working conditions and motivation had positive effect on the performance of agricultural extension agent, and the performance of agricultural extension agent affected the behavior of farmers in Rembang Regency. Characteristics, motivation and working conditions played an important role in improving and had impact to the performance of agricultural extension agent. Therefore this research suggest that agricultural extension agent need to increase their capacity through improve education and skill, attending training.

Keywords: performance, motivation, extension agent, behavior and agricultural. 


\section{PENDAHULUAN}

Sektor pertanian memegang peranan penting dalam pelaksanaan pembangunan. Hal ini dikarenakan sektor pertanian adalah satu-satunya sektor yang mampu menyediakan kebutuhan pangan, yang merupakan kebutuhan paling mendasar. Padi adalah tanaman pangan yang strategis hal ini disebabkan $90 \%$ penduduk Indonesia sumber pangan dan gizinya berasal dari padi. Kebutuhan pangan ini akan terus meningkat sejalan dengan pertumbuhan penduduk dan peningkatan konsumsi per kapita akibat peningkatan pendapatan.

Pembangunan pertanian dirasa masih lambat disebabkan oleh banyak hal, salah satunya adalah rendahnya kualitas SDM pertanian. Sumber daya manusia atau tenaga kerja merupakan faktor penggerak sektor pertanian. Tingkat pendidikan sebagian besar petani masih rendah, sehingga penguasaan akan pengetahuan dan teknologi juga menjadi lemah. Petani tidak berdaya terhadap aksesakses faktor produksi dan pasar (Tohir, 2015). Dalam rangka mewujudkan pertanian yang tangguh, maka diperlukan upaya pengembangan SDM pertanian yang profesional, kreatif, inovatif, kredibel dan berwawasan global (Hartati et al., 2011). Tohir (2015) mengemukakan peningkatkan kualitas sumber daya manusia pertanian hanya dapat diwujudkan melalui proses pendidikan yang berintikan pada pemberdayaan yaitu penyuluhan pertanian. Penyuluhan pertanian diharapkan dapat meningkatkan pengetahuan dan ketrampilan petani, merubah perilaku petani, serta kemandirian petani agar mampu mengelola usaha taninya secara produktif, efektif dan efisien.

Penyuluh pertanian berperan sebagai faktor penentu perubahan perilaku petani dalam pengembangan usaha tani karena penyuluh langsung membimbing petani hingga menghasilkan perubahan perilaku yang diharapkan (Muliady, 2009). Kinerja penyuluh pertanian yang baik berdampak pada perbaikan kinerja petani dalam meningkatkan produksi padi (Bahua et al., 2010).

Kinerja penyuluh pertanian merupakan perwujudan diri dari pelaksanaan tugas pokok seorang penyuluh sesuai dengan patokan yang telah ditetapkan. Dengan demikian seorang penyuluh pertanian dikatakan memiliki kinerja yang baik apabila sudah melaksanakan tugas pokok menurut standar tertentu (Supriani, 2014). Kinerja seorang penyuluh dapat dilihat dari pertama bahwa kinerja merupakan fungsi dari karakteristik individu, kedua bahwa kinerja merupakan pengaruh-pengaruh dari situasional diantaranya terjadi perbedaan pengelolaan dan penyelenggaraan penyuluhan pertanian di setiap Kabupaten (Leilani dan Jahi, 2016).

Setiap manusia memiliki karakteristik (pengetahuan, sikap dan ketrampilan) serta daya nalar dan kreativitas yang tidak selalu sama dengan orang lainnya. Karateristik seperti itu akan sangat menentukan kinerja dan produktivitasnya (Mardikanto, 2009). Prawirosentono dan Primasari (2015) mengungkapkan kinerja: kemampuan (kapasitas) ditambah motivasi, secara sederhana kemampuan dapat dilihat dari keahlian yang dimiliki, keahlian tersebut di pengaruhi oleh latar belakang pendidikan dan pengalaman.

Berdasarkan latar belakang tersebut diatas perlu dilakukan penelitian tentang pengaruh faktor karakteristik penyuluh (pendidikan, pelatihan, pengalaman kerja), faktor kondisi kerja (pengawasan, budaya organisasi, fasilitas, beban kerja, lingkungan fisik) dan motivasi (berprestasi, berafilitas, kekuasaan) kinerja penyuluh pertanian 
terhadap perilaku petani padi di Kabupaten Rembang. Tujuan yang ingin dicapai dalam penelitian ini adalah: 1. Menganalisis pengaruh karateristik penyuluh dengan kinerja penyuluh pertanian; 2. Menganalisis pengaruh kondisi kerja dengan kinerja penyuluh pertanian; 3. Menganalisis pengaruh motivasi dengan kinerja penyuluh pertanian; 4. Menganalisis pengaruh kinerja dengan perilaku petani di Kabupaten Rembang.

\section{METODE PENELITIAN}

Penelitian ini dilaksanakan di Kabupaten Rembang pada bulan Januari sampai dengan Maret 2017 dan merupakan penelitian kuantitatif analitik. Responden pada penelitian ini terdiri dari penyuluh pertanian di Kabupaten Rembang sebanyak 136 orang, kemudian untuk mengetahui out put kinerja penyuluh pertanian yaitu perilaku petani, dibutuhkan responden petani yang terdiri dari pengurus kelompok tani dan anggota kelompok tani binaan penyuluh pertanian sebesar 272 yang terdiri dari pengurus kelompok sebanyak 136 orang dan 136 anggota kelompok, yang diambil secara acak, yang tersebar pada 136 desa dan di 14 kecamatan di Kabupaten Rembang. Sebagaimana Muliady (2009), Bahua et al., (2010), Safaruddin, et al., (2011), Sapar et al., (2012), Sapar et al., (2014), Maksoud, (2015) yang kesemuanya dalam penelitiannya untuk mengukur out put kinerja penyuluh pertanian berupa perilaku petani menggunakan data petani yang menjadi binaan penyuluh pertanian.

Instrumen yang digunakan dalam penelitian ini terdiri dari 2 yaitu inturumen untuk penyuluh pertanian (karakteristik, kondisi keja, motivasi dan kinerja) dan intrumen untuk petani yaitu perilaku. Difinisi operasioanal dalam penelitian ini adalah 1 . Karakteristik penyuluh pertanian adalah bagian dari individu penyuluh yang mendasari tingkah lakunya dalam melaksanakan tugas, seperti pendidikan formal, pelatihan dan pengalaman kerja. 2 . Kondisi kerja adalah serangkaian kondisi atau kedaan lingkungan kerja dari suatu organisasi yang menjadi tempat bekerja. Serangkain kondisi tersebut antara lain pengawasan, budaya kerja, fasilitas, beban kerja dan lingkungan fisik. 3. Motivasi penyuluh merupakan dorongan dari dalam diri dan luar penyuluh ke suatu arah perilaku yang diawali oleh keinginan mengembangkan kreativitas dan mengarahkan semua kemampuan serta energi yang dimilikinya demi mencapai prestasi kerja yang optimal. Dorongan ini meliputi berprestasi, berafiliasi dan berkuasa. 4. Kinerja penyuluh pertanian adalah prestasi kerja atau hasil kerja yang dicapai penyuluh pertanian baik kualitas maupun kuantitas dalam periode tertentu yang terdiri dari persiapan, pelaksanaan dan pendapatan. 5. Perilaku petani padi adalah kompetensi petani dalam membudidayakan padi, partisipasi mereka dalam kegitan kelompoktani serta pendapatan dalam berusahatani.

Pengukuran instrumen menggunakan skor dengan skala Likert dengan interval 1 sampai dengan 5. Penentuan kreteria dengan rumus Interval $(\mathrm{I})=$ Range $(\mathrm{R}) /$ Kategori $(\mathrm{K})$, Range $(\mathrm{R})$ = Skor tertingi - Skor terendah, Kategori = banyaknya kriteria yang disusun pada kriteria objektif suatu variabel, kategori ada 3 yaitu = tinggi, sedang dan rendah. Data yang dikumpulkan kemudian dianalisis dengan SEM (Structural Equation Model) dengan menggunakan program AMOS (Ghozali, 2011).

HASIL DAN PEMBAHASAN

\section{Pengaruh Karakteristik Terhadap Kinerja Penyuluh Pertanian}

Karakteristik penyuluh pertanian adalah 
bagian dari individu penyuluh yang mendasari tingkah lakunya dalam melaksanakan tugas, seperti pendidikan formal, pelatihan dan pengalaman kerja. Karakteristik pada penelitian ini dibentuk dari indikator yang meliputi: pendidikan, pengalaman dan pelatihan. Hasil penelitian menunjukan bahwa karakteristik berpengaruh positif terhadap kinerja penyuluh pertanian, yang ditunjukkan dengan nilai probabilitas $=$ $0,019<0,05$.

Penelitian ini membuktikan bahwa karakteristik dapat meningkatkan kinerja penyuluh pertanian. Hal ini didukung dari penilaian responden penyuluh pertanian terhadap variabel yang diteliti cenderung pada kriteria tinggi yang tersaji pada Tabel 1.

Frekuensi relatif pendidikan penyuluh pertanian di Kabupaten Rembang sebanyak 73,5 \% masuk kategori tinggi hal ini mengidikasikan bahwa pendidikan yang diperoleh sangat membantu dalam meyelesaikan tugas sebagai penyuluh pertanian dan pendidikan akademis yang diperoleh dapat meningkatkan kualitas dan kemampuan untuk meningkatkan kinerja. Tetapi masih terdapat 26,5\% yang masuk kategori sedang, ini berarti perlu adanya upaya untuk mendorong variabel pendidikan penyuluh pertanian ketingkat yang lebih tinggi. Latar belakang pendidikan masih belum sesuai dengan bidang pekerjaan, hal ini dikarenakan penyuluh pertanian sekarang ini harus polivalen, jadi penyuluh pertanian harus bisa menguasai semua sektor pertanian antara lain : tanaman pangan, peternakan, dan perkebunan, walaupun sama-sama rumpun pertanian tetapi tidak bisa serta merta dengan mudah menguasai semua sektor-sektor tersebut, dibutuhkan jam terbang atau pengalaman. Penyuluh pertanian diharapkan dapat meningkatkan kapasitasnya melalui jenjang pendidikan yang lebih tinggi.

Pengalaman dapat mempengaruhi seseorang dalam menjalankan tupoksinya. Frekuensi relatif pengalaman sebesar 69,1\% masuk kategori tinggi dan sebesar 30,9\% masuk kategori sedang, hal ini berarti perlu adanya upaya untuk meningkatkan pengalaman ketingkat yang lebih tinggi, pengalaman yang dimiliki belum menyelesaiakan masalah-masalah yang dihadapi oleh penyuluh sehingga diperlukan pelatihan yang sesuai dengan kebutuhan.

Pelatihan memegang peranan yang signifikan dalam mengembangkan sumberdaya manusia, dan hanya dengan karyawan yang terlatih dan efisien suatu organisasi dapat mencapai tujuannya. Frekuensi relatif pelatihan penyuluh pertanian di Kabupaten Rembang sebesar 76,4 \% masuk kategori tinggi ini mengidikasikan pelatihan merupakan proses pembelajaran penguasaan pengetahuan, meningkatkan

Tabel 1. Capaian Skor Variabel Pendidikan, Pengalaman, Pelatihan Penyuluh Pertanian di Kabupaten Rembang

\begin{tabular}{lccc}
\hline & Pendidikan & Pengalaman & Pelatihan \\
\hline Rata-rata & 12,42 & 12,21 & 12,47 \\
Standar Deviasi & 1,473 & 1,420 & 1,344 \\
\hline Kriteria & & Frekuensi Relatif (\%) & \\
\hline Rendah & 0 & 0 & 0 \\
Sedang & 26,5 & 30,9 & 23,6 \\
Tinggi & 73,5 & 69,1 & 76,4 \\
\hline
\end{tabular}

Sumber: Data primer yang diolah, 2017 
ketrampilan serta perubahan sikap dan perilaku guna meningkatkan kinerja. Sebesar 23,6 \% masuk kategori sedang, ini berarti masih perlu dilakukan upaya untuk peningkatan. Masalah pelatihan yang di ikuti masih belum sesuai dengan kebutuhan yang ada, masih bersifat general yang masih sulit untuk di terapkan di wilayah binaan.

Semakin baik pendidikan maka kinerja penyuluh pertanian makin tinggi. Sebagaimana pendapat Kadarisman (2013) bahwa seorang pegawai yang mempunyai pendidikan lebih tinggi, akan lebih mudah termotivasi untuk bekerja lebih baik. Penyuluh yang sudah mempunyai pengetahuan dan wawasan yang lebih luas kinerjanya lebih baik, dibandingkan dengan penyuluh yang berpendidikan lebih rendah. Pengetahuan dan wawasan yang lebih luas yang dimiliki penyuluh tersebut akan memudahkan penyuluh untuk mengerti dan memahami serta mengatisipasi perkembangan organisasi dan lebih mengetahui apa yang dibutuhkan organisasi.

Penyuluh pertanian yang memiliki pengalaman kerja lebih banyak, maka kinerjanya akan lebih baik. Pengalaman tentang keberhasilan atau kegagalan mengatasi atau memecahkan suatu masalah yang sulit atau yang tidak bisa terjadi dalam melakukan pekerjaan merupakan referensi berharga yang membuat kinerja pegawai menjadi lebih baik (Suparyadi, 2015). Referensi lebih banyak membuat penyuluh minim mengulangi kesalahan sehingga dikatakan kinerjanya lebih meningkat. Menurut Sukino (2014), pelatihan bertujuan untuk mengembangkan pengetahuan, ketrampilan dan sikap. Penyuluh yang telah menempuh pelatihan penguasaan keahlian tertentu lebih mudah menyelesaikan masalah yang dihadapi dalam pengembangan pertanian.
Hasil penelitian ini sejalan dengan Muliady (2009), yang menyatakan bahwa hubungan karakteristik pada kinerja penyuluh pertanian menunjukkan berpengaruh nyata pada kinerja. Bahua et al. (2010) mengemukakan variabel karakteristik berpengaruh nyata pada kinerja penyuluh pertanian, berarti karakteristik ikut menentukan baik dan buruknya kinerja penyuluh pertanian. Supriani (2014) juga menyatakan hal yang sama bahwa secara bersama-sama (simultan) umur penyuluh, jumlah pelatihan, masa kerja, berpengaruh secara signifikan (nyata) terhadap kinerja penyuluh pertanian di Kabupaten Majene. Triasmoro (2012) yang menyatakan bahwa kemampuan pegawai memiliki pengaruh yang positif dan signifikan terhadap kinerja dan kemampuan pegawai (kecekatan, pelatihan dan pendidikan).

\section{Pengaruh Kondisi Kerja Terhadap Kinerja Penyuluh Pertanian}

Kondisi kerja adalah serangkaian kondisi atau kedaan lingkungan kerja dari suatu organisasi yang menjadi tempat bekerja, kondisi kerja pada penelitian ini dibentuk dari indikator: pengawasan, budaya organisasi, fasilitas, beban kerja, dan lingkungan fisik. Hasil penelitian membuktikan bahwa ada pengaruh kondisi kerja terhadap kinerja penyuluh pertanian, dengan probabilitas = $0,000<0,05$. Hal ini didukung dari data penilaian responden penyuluh pertanian terhadap variabel yang diteliti pada kriteria tinggi yang tersaji pada Tabel 2.

Berdasarkan Tabel 2. dapat diketahui bahwa variabel pengawasan dipilih responden sebanyak 86,7 \% pada kategori tinggi ini berarti pengawasan dilakukan untuk menjaga tugas dan fungsi tidak menyimpang dari aturan. Sebesar 13,3\% pada kategori sedang dan pada kategori rendah $0 \%$. Hal ini masih perlu upaya peningkatan salah satu yang 
Tabel 2. Capaian Skor Variabel Pengawasan, Budaya, Fasilitas, Beban Kerja dan Lingkungan Penyuluh Pertanian di Kabupaten Rembang

\begin{tabular}{|c|c|c|c|c|c|}
\hline & Pengawasan & Budaya & Fasilitas & Beban & Lingkungan \\
\hline Rata-Rata & 12,68 & 16,66 & 12,47 & 15,04 & 11,74 \\
\hline Standar Deviasi & 1,310 & 2,005 & 1,344 & 1,763 & 1,554 \\
\hline Kriteria & \multicolumn{5}{|c|}{ Frekuensi Relatif (\%) } \\
\hline Rendah & 0 & 0 & 3,7 & 0 & 0 \\
\hline Sedang & 13,3 & 31 & 50,1 & 57,3 & 42,6 \\
\hline Tinggi & 86,7 & 69 & 46,3 & 42,6 & 57,4 \\
\hline
\end{tabular}

Sumber: Data primer yang diolah, 2017

menjadi hambatan dalam pelaksanaan pengawasan atau supervisi di Kabupaten Rembang adalah pelaksanaan pengawasan dilaksanakan secara insidentil masih belum secara rutin dan berkala. Variabel budaya dipilih oleh responden sebesar $69 \%$ masuk pada kriteria tinggi hal ini mengindikasikan bahwa disiplin organisasi di tegakkan, dan sebesar $31 \%$ pada kriteria sedang dan $0 \%$ pada kriteria rendah. Perlu upaya meningkatkan $31 \%$ kriteria sedang menuju ke kriteria tinggi. Tingkat kebersamaan anggota organisasi masih dianggap kurang. Tingkat bersamaan anggota organisasi dapat ditingkatkan dengan mengadakan acara yang melibatkan seluruh anggota organisasi yang didalamnya memupuk rasa kebersamaan.

Variabel fasilitas dipilih oleh responden sebesar 46,3 \% masuk pada kriteria tinggi, $50,1 \%$ pada kriteria sedang, dan sebesar 3,7 $\%$ masuk kategori rendah. Masalah yang dihadapi antara lain bagunan gedung kantor atau Balai Penyuluhan Pertanian Kecamatan mulai mengalami kerusakan dan sarana transportasi yang masih belum memadai. Dengan adanya Undang - Undang 23 Tahun 2014 tentang Pemerintah Daerah, anggaran untuk penyuluhan pertanian berkurang drastis, sehingga bangunan kantor yang mengalami kerusakan masih belum bisa dibenahi dan sarana trasnportasi yang layak masih belum memadai. Variabel beban kerja dipilih oleh responden sebesar 46,3\% masuk pada kriteria tinggi, 50,1 \% pada kriteria sedang, dan sebesar $0 \%$ masuk kategori rendah. Masih terdapat 50,1\% yang masuk kriteria sedang yang harus didorong kekriteria tinggi. Persepsi responden yang masih menjadi hambatan pada variabel beban kerja adalah pekerjaan di luar tugas pokok dan fungsi tidak sesuai.

Variabel lingkungan dipilih oleh responden sebesar 57,4\% masuk pada kriteria tinggi, 42,6 \% pada kriteria sedang, dan sebesar $0 \%$ masuk kategori rendah. Sehingga masih ada 42,6 \% yang harus ditingkatkan. Menurut persepsi responden kondisi iklim wilayah binaan tidak mendukung. Kondisi iklim ini yang tidak mendukung adalah keterbatasan air dari 14 kecamatan yang mempunyai irigrasi teknis hanya terdapat 3 kecamatan sisanya menggantungkan pada air hujan. Sehingga diperlukan alternative tanaman yang tidak banyak membutuhkan air, sementara ini yang dikembangkan adalah tanaman palawija (jagung, kedelai) dan tanaman perkebunan (tembakau, tebu, kelapa).

Pengawasan yang berfungsi dengan baik akan mendorong kinerja penyuluh pertanian juga menjadi lebih baik. Kadarisman (2013) menyatakan pengawasan sebagai salah satu fungsi manajemen merupakan suatu proses yang tidak terputus untuk menjaga agar pelaksanaan tugas, fungsi, dan wewenang tidak menyimpang dari 
aturan yang telah ditetapkan dalam rangka mencapai tujuan organisasi. Pada proses penyuluhan, pengawasan diistilahkan supervisi, dan supervisi dilakukan secara berjenjang untuk mengontrol bahwa penyuluhan yang dilakukan berjalan dengan baik, sehingga apabila terjadi masalah akan segera mendapatkan solusi. Supervisi dilakukan secara rutin dan berkala untuk menjamin terwujudnya transfer teknologi dari penyuluh kepada petani. Budaya organisasi juga berperan penting dalam peningkatan kinerja pegawai. Budaya organisasi yang kuat, membuat para penyuluh pertanian mendapatkan suatu pemahaman yang jelas dari tugas-tugas yang diberikan oleh organisasi, berpengaruh besar terhadap perilaku anggota-anggotanya, karena tingginya tingkat kebersamaan. Budaya organisasi yang tinggi membuat penyuluh pertanian dapat membangun kesetiaan terhadap organisasi dan komitmen bersama saling bantu dalam melaksanakan tugas penyuluhan, sehingga kinerja penyuluh akan lebih baik. Menurut Moeljono (2003), budaya organisasi adalah sistem nilai-nilai yang diyakini oleh semua anggota organisasi dan yang dipelajari, diterapkan serta dikembangkan secara berkesinambungan, berfungsi sebagai sistem perekat dan dijadikan acuan perilaku dalam organisasi untuk mencapai tujuan perusahaan yang telah ditetapkan.

Kondisi kerja yang menyenangkan seperti fasiltas yang memadai, akan meningkatkan kinerja penyuluh. Secara umum fasilitas penyuluhan cukup memadai, hal ini menunjukkan bahwa kelengkapan fasilitas penyuluhan akan mendorong penyuluh untuk bekerja secara giat. Jika fasilitas tidak mendukung maka ada kemungkinan untuk bekerja secara malas cukup besar. Disamping fasilitas, beban kerja yang tidak berlebihan akan meningkatkan kinerja pegawai. Pada penelitian ini, perbandingan jumlah penyuluh pertanian dengan jumlah kelompok tani masih cukup sesuai. Satu penyuluh pertanian membina delapan sampai dengan dua belas kelompok tani atau antara dua desa sampai tiga desa sehingga beban pekerjaan masih dianggap wajar. Kementerian Pertanian, 2016 mengemukakan bahwa penyuluh pertanian dapat membina delapan kelompok tani sampai dengan enam belas kelompok tani. Beban kerja yang masih wajar ini dapat meningkatkan kinerja. Beban kerja pegawai perlu diperhatikan agar tidak terjadi kelebihan, yang dapat menimbulkan stres dan dapat berakibat pada menurunya kinerja karyawan. (Mudayana, 2012). Lingkungan fisik yang mendukung berdampak pada peningkatan kinerja pegawai. Penelitian ini menemukan bukti lingkungan fisik penyuluh pertanian sangat mendukung, hal ini dapat dilihat dari kondisi geografis wilayah binaan yang masih mudah untuk dijangkau, tidak ada yang mempunyai kontur naik turun. Kondisi iklim wilayah binaan yang cukup mendukung untuk berbudidaya pertanian.

Penelitian ini sejalan dengan Aisha et al. (2013) yang menunjukkan bahwa variabel kondisi kerja memiliki pengaruh yang signifikan terhadap kinerja karyawan. Kondisi kerja yang baik meningkatkan kinerja karyawan. Fasilitas dan beban kerja memiliki efek yang negatif terhadap kinerja, fasilitas yang tidak baik atau kurang standar mengakibatkan kinerja pegawai menurun, begitu juga beban kerja yang berlebihan akan mempengaruhi kinerja karyawan.

\section{Pengaruh Motivasi Terhadap Kinerja Penyuluh Pertanian}

Motivasi penyuluh merupakan dorongan dari dalam diri dan luar penyuluh ke suatu arah perilaku yang diawali oleh 
keinginan mengembangkan kreativitas dan mengarahkan semua kemampuan serta energi yang dimilikinya demi mencapai prestasi kerja yang optimal. Dorongan ini meliputi berprestasi, berafiliasi dan berkuasa.Motivasi dalam penelitian ini dibentuk dari indikator : berprestasi, berafilitas, dan berkuasa. Hasil penelitian membuktikan bahwa ada pengaruh motivasi terhadap kinerja penyuluh pertanian menunjukkan nilai koefisien dengan probabilitas $=0,027<0,05$. Hasil ini memberi arti bahwa semakin tinggi motivasi penyuluh pertanian maka kinerjanya semakin tinggi. Sebaliknya semakin rendah motivasi penyuluh pertanian maka kinerjanya akan semakin rendah atau buruk. Hal ini didukung dari penilaian responden terhadap variabel yang diteliti cenderung pada kriteria tinggi yang tersaji pada Tabel 3 .

Menurut Tabel 3. variabel berprestasi yang paling dominan pada kriteria tinggi sebesar $83,7 \%$ hal ini teridentifikasikan selalu ingin untuk meraih sukses dalam pekerjaan, dorongan maju dalam pekerjaan. Kriteria sedang sebesar 16,3\% dan kriteria rendah sebanyak $0 \%$. Masih terdapat $16,3 \%$ yang masuk pada kriteria sedang sehingga perlu didorong masuk pada kriteria tinggi. Responden merasa bahwa penghargaan terhadap penyuluh pertanian masih belum ada, diharapkan adanya pengakuan eksistensi penyuluh melalui penghargaan penyuluh pertanian teladan.

Variabel berafilitas dominan pada kriteria tinggi sebesar 79,4\% tergambarkan mendapatkan respon yang baik dari petani, kriteria sedang sebesar 20,6\% dan kriteria rendah sebanyak $0 \%$, dengan demikian perlu ditingkatkan. Menurut persepsi responden keberadaan penyuluh masih belum dihargai oleh petani sehingga perlu adanya upaya mendekatkan dengan petani dengan cara kunjungan secara rutin dan berkala dan juga menberikan materi penyuluhan yang dibutuhkan oleh petani.

Variabel berkuasa yang paling dominan pada kriteria tinggi sebesar $43,2 \%$ hal ini tergambarkan ide dan informasi yang diberikan penyuluh selalu diperhatikan. Masih terdapat 55,3\% dan 1,5\% yang masuk pada kriteria sedang dan rendah sehingga perlu didorong masuk pada kriteria tinggi. Masih ada yang memiliki persepsi bahwa tidak ingin mencapai posisi lebih tinggi dalam pekerjaan.

Penyuluh yang mempunyai motivasi berprestasi tinggi maka kinerjanya lebih baik. Penyuluh pertanian mempunyai motivasi menjadi penyuluh pertanian teladan dan keinginan kuat dari penyuluh agar kelompok tani binaan mendapatkan penghargaan. Motivasi berprestasi inilah yang menjadi pendorong penyuluh pertanian untuk bekerja lebih giat, penyuluh pertanian aktif mendampingi kelompok tani dalam setiap kesempatan. Pegawai yang mempunyai motivasi berafiliasi tinggi akan membuat kinerja pegawai menjadi lebih baik, artinya

Tabel 3. Capaian Skor Variabel Berprestasi, Berafilitas, Berkuasa Penyuluh Pertanian di Kabupaten Rembang.

\begin{tabular}{lrcr}
\hline & Berprestasi & Berafilitas & Berkuasa \\
\hline Rerata & 20,95 & 17,08 & 19,02 \\
Standar Deviasi & 2,120 & 2,000 & 2,390 \\
\hline Kriteria & & Frekuensi Relatif (\%) \\
\hline Rendah & 0 & 0 & 1,5 \\
Sedang & 16,3 & 20,6 & 55,3 \\
Tinggi & 83,7 & 79,4 & 43,2 \\
\hline
\end{tabular}

Sumber: Data primer yang diolah, 2017 
dorongan pegawai untuk memenuhi kebutuhan akan dukungan dalam hubungan dengan individu lain, kebutuhan yang tinggi akan afiliasi adalah kebutuhan yang mengarahkan tingkah laku untuk mengadakan hubungan secara akrab dengan individu lain (Sutrisno, 2010). Pada penelitian ini ditemukan bahwa motivasi berafiliasi penyuluh pertanian apabila dihargai keberadaanya dan mendapatkan respon positif dari petani, akan meningkatkan intensitas kunjungan ke kelompok tani. Ide-ide dan informasi yang selalu diperhatikan oleh kelompok tani menjadi faktor pendorong untuk meningkatkan kinerja.

Kebutuhan menguasai dan mempengaruhi orang lain mendorong penyuluh untuk menunjukkan kinerja unggul. Keinginan penyuluh untuk memenuhi kebutuhan berkuasa bisa dijelaskan bahwa sebagai penyuluh yang diberi tanggung jawab di bidang pertanian maka sangat berkeinginan memajukan nasib para petani. Hasil penelitian ini sejalan dengan Triasmoro (2012) yang menyatakan bahwa motivasi berpengaruh positif terhadap kinerja.

Muliady (2009) mengungkapkan bahwa motivasi berperan penting untuk meningkatkan kinerja penyuluh pertanian. Penyuluh pertanian yang mempunyai motivasi tinggi maka akan lebih aktif melakukan penyuluhan kepada petani. Motivasi tinggi mampu sebagai pendorong semangat bagi penyuluh pertanian, untuk melakukan penyuluhan lebih rutin sehingga perilaku dari petani binaan menjadi lebih baik. Supriani (2014) mengemukakan faktor yang paling dominan berpengaruh terhadap kinerja penyuluh pertanian di Kabupaten Majene adalah faktor motivasi kerja penyuluh, faktor motivasi meliputi pengembangan potensi diri dan kebutuhan untuk berafiliasi. Sapar et al. (2012) mengemukakan motivasi (kebutuhan untuk berpartisipasi, berafiliasi) berpengaruh pada kinerja penyuluh peranian.

\section{Pengaruh Kinerja Penyuluh Pertanian Terhadap Perilaku Petani}

Perilaku petani dalam penelitian ini dibentuk dari indikator : kompetensi, partisipasi, dan pendapatan. Hasil penelitian terbukti bahwa kinerja berpengaruh positif dan signifikan terhadap perilaku petani dengan probabilitas $=0,001<0,05$. Hasil ini memberi arti bahwa semakin tinggi kinerja pegawai penyuluh pertanian maka perilaku petani juga semakin baik. Sebaliknya semakin rendah kinerja penyuluh pertanian maka perilaku petani akan semakin buruk. Hal ini didukung dari penilaian responden terhadap variabel kinerja yang diteliti cenderung pada kriteria tinggi yang tersaji pada Tabel 4.

Kinerja merupakan hasil kerja yang telah dicapai seseorang atau sekelompok orang dalam suatu organisasi sesuai wewenang dan tanggung jawab masing masing. Tabel 4. menunjukkan bahwa frekuensi relative persiapan, pelaksanaan dan evaluasi pembentuk variabel kinerja, pada variabel persiapan dominan pada kriteria tinggi sebesar 75,7 \% karena tergambarkan pada memberikan bimbingan penyusunan Rencana Definitif Kebutuhan Kelompok, menyusun programa penyuluhan, membuat rencana kerja tahunan penyuluh yang sudah terlaksana dengan baik. Kriteria sedang sebesar 24,3\% dan kriteria rendah sebanyak 0 $\%$. Hasil tersebut dapat disimpulkan bahwa sebesar $24,3 \%$ penyuluh perlu didorong untuk meningkatkan kinerja pada persiapan penyuluhan, terutama pada pekerjaan membuat data potensi wilayah dan agroekosistem.

Variabel pelaksanaan pada kriteria tinggi sebesar $48,6 \%$, hal ini tergambarkan dalam melaksanakan desiminasi / penyebaran 
Tabel 4. Capaian Skor Variabel Persiapan, Pelaksanaan, Evaluasi Penyuluh Pertanian Di Kabupaten Rembang

\begin{tabular}{lrrr}
\hline & Persiapan & Pelaksanaan & Evaluasi \\
\hline Rerata & 16,51 & 34,22 & 7,28 \\
Standar Deviasi & 1,757 & 4,605 & 1,274 \\
\hline Kriteria & & Frekuensi Relatif (\%) & \\
\hline Rendah & 0 & 0 & 24,3 \\
Sedang & 24,3 & 51,3 & 53,7 \\
Tinggi & 75,7 & 48,6 & 22 \\
\hline
\end{tabular}

Sumber: Data primer yang diolah, 2017

materi penyuluhan sesuai kebutuhan petani, melaksanakan penerapan metode penyuluhan pertanian di wilayah binaan dalam bentuk kunjungan / tatapmuka, kriteria sedang sebesar 50,3\% dan kriteria rendah sebanyak $0 \%$. Pada variabel pelaksanaan ini masih terdapat $50,3 \%$ yang masuk pada kriteria sedang sehingga perlu didorong ke arah kriteria tinggi. Kegiatan yang perlu didorong adalah menumbuhkan dan mengembangkan kelembagaan petani. Melaksanakan penerapan metoda penyuluhan pertanian di wilayah binaan dalam bentuk kursus.

Variabel evaluasi masuk pada kriteria tinggi sebesar 22\%. Kriteria ini terindikasikan pada melaksanakan evaluasi pelaksaaan penyuluhan pertanian. Kriteria sedang sebesar $53,7 \%$ dan kriteria rendah sebanyak $24,3 \%$. Kegiatan yang harus didorong dalam variabel evaluasi adalah membuat laporan pelaksanaan penyuluhan pertanian. Laporan pelaksanaan penyuluhan sangat penting untuk dilakukan sebagai bukti bahwa penyuluh telah melaksanakan kegiatan penyuluhan.
Sebagaimana Mujiburahmad

mengemukakan bahwa kinerja penyuluh pertanian di Kabupaten Pidi aspek yang rendah evaluasi dan pelaporan.

Perilaku petani padi adalah kompetensi petani dalam membudidayakan padi, partisipasi mereka dalam kegitan kelompok tani serta pendapatan dalam berusahatani. Variabel perilaku petani ditunjukkan pada Tabel 5.

Frekuensi relatif kompetensi, partisipasi dan pendapatan pembentuk variabel perilaku, pada variabel kompetensi yang paling dominan pada kriteria tinggi sebesar 56,8\% tergambarkan dengan mampu mengolah lahan untuk tanaman padi, menyemai benih padi, memupuk tanaman padi, merontokan padi. Kriteria sedang sebesar $43,2 \%$ dan kriteria rendah sebanyak $0 \%$. Hasil tersebut dapat disimpulkan bahwa sebesar 43,2\% harus perlu didorong untuk ditingkatkan kompetensinya, terutama pada mengidentifikasi kondisi benih padi, dan pada mengakses pada lembaga permodalan.

Tabel. 5. Capaian Skor Variabel Kompetensi, Partisipasi, Pendapatan Penyuluh Pertanian Di Kabupaten Rembang

\begin{tabular}{lccc}
\hline & Kompetensi & Partisipasi & Pendapatan \\
\hline Rata-Rata & 45,39 & 22,34 & 11,452 \\
Standar Deviasi & 4,909 & 2,620 & 1,469 \\
\hline Kriteria & \multicolumn{3}{c}{0} \\
\hline Rendah & 0 & Frekuensi Relatif \% & \\
Sedang & 43,2 & 0 & 50,7 \\
Tinggi & 56,8 & 56,6 & 49,3 \\
\hline
\end{tabular}

Sumber: Data primer yang diolah, 2017 
Penyuluhan pertanian perlu ditingkatkan mengenai mengidentifikasi benih padi dan mengenalkan akses terhadap lembaga permodalan.

Variabel partisipasi kriteria tinggi sebesar $48,6 \%$, kriteria sedang sebesar 50,3\% tergambarkan dalam kegiatan hadir pada pertemuan kelompok tani, mengikuti kegiatan penyuluhan, dan kriteria rendah sebanyak $0 \%$. Pada variabel partisipasi ini masih terdapat $50,3 \%$ yang masuk pada kriteria sedang yang perlu didorong kearah kriteria tinggi. Item yang masih agak kurang pada kegiatan membayar iuran kelompok. Kegiatan tersebut yang perlu didorong untuk meningkatkan partisipasi dalam kelompok. Iuran kelompok merupakan salah satu bentuk partisipasi anggota kelompok agar kegiatan kelompok tani tetap bisa berjalan.

Variabel pendapatan kriteria tinggi sebesar 49,3\%, tergambarkan dengan setelah mengikuti penyuluhan pertanian pendapatan meningkat salah satunya adalah tanah jajar legowo dapat meningkatkan produksi 20$30 \%$. Kriteria sedang sebesar $50,7 \%$ harus didorong untuk ditingkatkan ke kriteria tinggi. Menurut persepsi responden setelah mengikuti penyuluhan pertanian pengunaan biaya produksi belum efisien. Apabila dilihat lebih mendalam penggunaan sarana dan prasarana produksi masih belum berubah contohnya pada penggunaan pupuk anorganic masih cukup tinggi. Responden masih menggunakan pupuk anorganik sesuai dengan dosis yang umum padahal penggunaan pupuk anorganik di tanah yang satu dengan tanah yang lain tidak sama. Oleh sebab itu penyuluh pertanian diharapkan dapat melaksanakan ujicoba spesifik lokalita agar dapat merekomendasikan dosis pupuk yang tepat.

Kompetensi merupakan suatu kemampuan untuk melaksanakan atau melakukan suatu pekerjaan atau tugas yang dilandasi atas ketrampilan dan pengetahuan serta didukung oleh sikap kerja yang dituntut oleh pekerjaan tersebut. Dengan demikian, kompetensi menunjukkan ketrampilan atau pengetahuan yang dicirikan oleh profesionalisme dalam suatu bidang tertentu sebagai sesuatu yang terpenting, sebagai unggulan bidang tersebut (Wibowo 2012). Penyuluh pertanian yang giat melakukan kegiatan penyuluhan maka petani akan lebih banyak mendapatkan informasi mengenai cara bertani yang baik dan benar. Dampak dari banyaknya informasi yang didapatkan dari kegiatan penyuluhan oleh penyuluh menjadikan petani mempunyai kompetensi yang lebih baik dan secara langsung akan meningkatkan pendapatannya.

Partisipasi menurut Mardikanto (2009) adalah keikutsertaan seseorang atau sekelompok anggota masyarakat dalam suatu kegiatan. Menurut Mardikanto (2009), salah satu indikator keberhasilan pemberdayaan masyarakat adalah jumlah warga yang secara nyata tertarik untuk hadir dalam kegiatan yang dilaksanakan. Kegiatan penyuluhan melalui pendekatan kelompok dimaksudkan untuk mendorong terbentuknya kelembagaan petani yang mampu membangun sinergi antar petani dan antar poktan dalam rangka mencapai efisiensi usaha. Selanjutnya dalam rangka meningkatkan kemampuan poktan dilakukan pembinaan dan pendampingan oleh penyuluh pertanian, dengan melaksanakan penilaian klasifikasi kemampuan poktan secara berkelanjutan yang disesuaikan dengan kondisi perkembangannya (Kementrian Pertanian, 2016). Pada penelitian ini partisipasi petani dalam kelompok relatif sering, indikasi bahwa anggota kelompok00 tersebut bersedia datang disetiap kegiatan, dan aktif memberikan tanggapan atau aktif melakukan kegiatan dan juga ikut serta mengambil keputusan bersama. 
Departemen Pertanian (2002) menyatakan bahwa penyuluhan pertanian adalah pemberdayaan petani dan keluarganya beserta masyarakat pelaku agribisnis melalui kegiatan pendidikan non formal di bidang pertanian agar mereka mampu menolong dirinya sendiri di bidang ekonomi dan sosial. Penelitian ini dapat dilihat bahwa peningkatan pendapatan petani dari sebelum dilakukan penyuluhan dan sesudah dilaksanakan penyuluhan, peningkatan pendapatan ini disebabkan adanya penerapan inovasi oleh petani hasil dari materi yang telah disuluhkan oleh penyuluh, diantaranya penggunaan bibit unggul bersetifikat, tanaman jajar legowo, sehingga menjadikan produksi padi dengan kualitas yang bagus pada akhirnya meningkatkan harga jual.

Penghematan/ efisiensi biaya produksi juga menyumbang peningkatan pendapatan, apabila dilihat lebih dalam lagi biaya produksi ini dipengaruhi oleh biaya tenaga kerja dan biaya sarana produksi (pupuk dan pestisida). Setelah diuji beda menunjukkan bahwa biaya tenaga kerja sebelum dan sesudah penyuluhan terdapat perbedaan yang nyata, tetapi biaya sarana produksi masih belum menunjukan perbedaan yang nyata. Kondisi ini disebabkan petani masih belum menerapkan dosis pemupukan yang spesifik lokasi, masih menerapkan dosis pemupukan yang umum pada hal kondisi tanah masingmasing petani berbeda-beda kandungan unsur haranya.

Kinerja penyuluh pertanian yang tinggi berpengaruh terhadap kompetensi, partisipasi dan pendapatan petani. Hasil penelitian ini sejalan dengan penelitian Muliady (2009) dan Bahua et al. (2010), bahwa kinerja penyuluh pertanian dapat meningkatkan perilaku petani melalui dimensi kompetensi dan partisipasi. Mardikanto (2009) mengemukakan bahwa efektivitas atau keberhasilan suatu kegiatan penyuluhan dapat diukur dari sejauh mana telah terjadi perubahan perilaku (petani) penerima manfaat, yang kesemuanya itu dapat diamanti pada: (1). Perubahanperubahan pelaksanaan kegiatan bertani yang mencakup macam dan jumlah sarana atau teknik bertaninya, (2). Perubahan-perubahan tingkat produktivitas dan pendapatannya.

\section{Model Analisis Pengaruh Karakteristik, Kondisi Kerja, Motivasi Terhadap Kinerja Penyuluh Pertanian dan Pada Perilaku Petani Padi}

Analisis full model SEM terdapat 17 indikator, didapatkan semua indikator memenuhi nilai faktor loadingnya, sehingga semua indikator memenuhi syarat untuk dianalisis full model. Pada Gambar 1 menunjukkan nilai $P$-hitung sebesar $0,565>$ 0.05 ; RMSEA $0,000<0.08$; GFI sebesar $0,924>0.90$; AGFI 0,888<0.90; TLI 1,005 $>0,95$; CFI 1,000 > 0.95. Berdasarkan hasil tersebut, secara keseluruhan nilainya telah memenuhi cut of value yang ditentukan. Dapat diartikan bahwa Ho diterima atau H1 ditolak artinya model yang diuji mampu mengestimasi matrik kovariansi atau matrik kovariansi data sampel berbeda dengan matrik kovariansi populasi yang diestimasi sehingga dapat disimpulkan bahwa pengujian kesuaian model Gambar 1 menunjukkan model pengukuran fit dengan data.

Uji goodness of fit model bertujuan untuk menguji kelayakan model secara keseluruhan. Uji goodness of fit model disajikan pada Tabel 6. Setelah asumsi dapat dipenuhi, selanjutnya dilakukan pengujian hipotesis. Pengujian hipotesis penelitian ini dilakukan berdasarkan nilai $\mathrm{t}$ dari suatu hubungan kausalitas dari hasil pengolahan SEM. Untuk menguji penerimaan hipotesis penelitian sebagaimana diajukan sebelumnya maka selanjutnya dibahas dengan berdasarkan pada hasil SEM pada Tabel 7. 


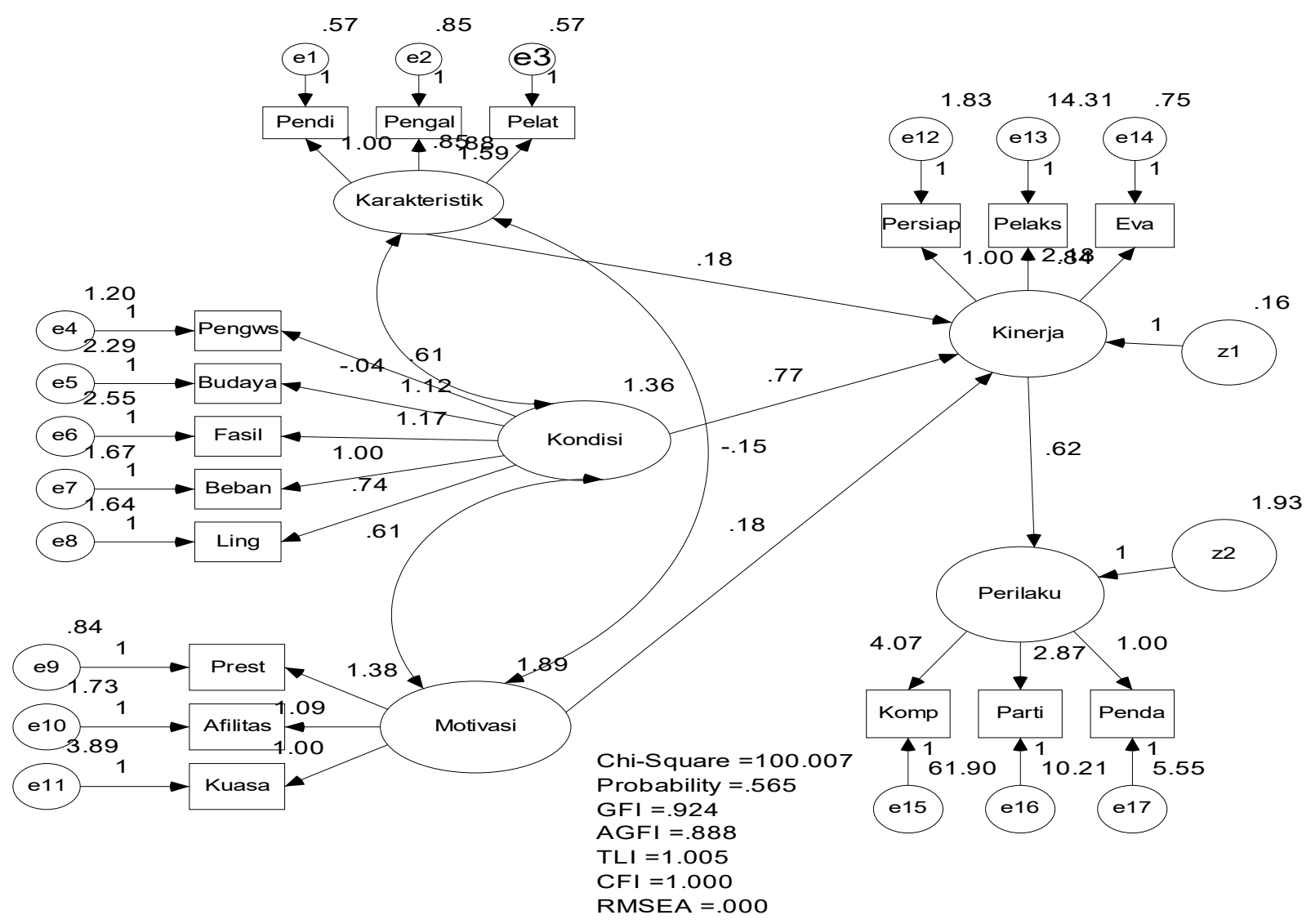

Gambar 1. Estimasi Seluruh Parameter Model Persamaan Struktural

Tabel 6. Hasil Pengujian Kelayakan Model

\begin{tabular}{lrrc}
\hline \multicolumn{1}{c}{ Goodness of Fit Index } & Cut Of value & Hasil Olah Data & Evaluasi Model \\
\hline Chi-Square & $\leq 127,69$ & 100,007 & Fit \\
Probability & $\geq 0,05$ & 0,565 & Fit \\
GFI & $\geq 0,90$ & 0,924 & Fit \\
AGFI & $\geq 0,90$ & 0,888 & Marjinal \\
TLI & $\geq 0,95$ & 1,005 & Fit \\
CFI & $\geq 0,95$ & 1,000 & Fit \\
CMIN/DF & $\leq 2,00$ & 0,971 & Fit \\
RMSEA & $\leq 0,08$ & 0,000 & Fit \\
\hline
\end{tabular}

Sumber: Data yang dikembangkan dalam penelitian ini

Tabel 7. Regression Weight Structural Equational

\begin{tabular}{llrrrrl}
\hline & & Estimate & S.E. & \multicolumn{1}{l}{ C.R. } & \multicolumn{1}{c}{ P } & Label \\
\hline Kinerja $<---$ & Karakteristik & 0.183 & 0.078 & 2.347 & 0.019 & par_14 \\
Kinerja $<---$ & Kondisi & 0.768 & 0.144 & 5.337 & $* * *$ & par_13 \\
Kinerja $<---$ & Motivasi & 0.177 & 0.080 & 2.212 & 0.027 & par_12 \\
Perilaku $<---$ & Kinerja & 0.621 & 0.189 & 3.284 & 0.001 & par_16 \\
\hline
\end{tabular}

Sumber: Data primer yang diolah, 2017 
Berdasarkan Tabel 7 dapat diketahui estimasi parameter model struktural, dapat dituangkan dalam persamaan model struktural sebagai berikut:

Persamaan model Struktural:

$\mathrm{Y} 1=0,183 \mathrm{X} 1+0,768 \mathrm{X} 2+0,177 \mathrm{X} 3+0,16$

$\mathrm{Y} 2=0,621 \mathrm{Y} 1+1,93$

Keterangan :

Y1: Kinerja Penyuluh Pertanian

Y2: Perilaku Petani

$\mathrm{X} 1$ : Karakteristik

$\mathrm{X} 2$ : Kondisi Kerja

X3: Motivasi

\section{SIMPULAN DAN SARAN}

Berdasarkan hasil penelitian, kesimpulan yang dapat diambil adalah karakteristik penyuluh berpengaruh positif dan signifikan terhadap kinerja penyuluh pertanian. Kondisi kerja berpengaruh positif dan signifikan terhadap kinerja penyuluh pertanian. Motivasi berpengaruh positif dan signifikan terhadap kinerja penyuluh pertanian. Kesimpulan berikutnya adalah kinerja penyuluh pertanian berpengaruh positif dan signifikan terhadap perilaku petani.

\section{DAFTAR PUSTAKA}

Aisha, A.N., P. Hardjomidjojo, and Yassierli. 2013. Effects of working ability, working kondition, motivation and incentive on employees multidimensional performance. International Journal of Innovation, Management and Technology 4 (6): 605-609.

Bahua, M I., A. Jahi, P.S. Asngari, A. Saleh, dan I.G.P. Purnaba. 2010. Faktor-faktor yang mempengaruhi kinerja penyuluh pertanian dan dampaknya pada perilaku petani jagung di provinsi gorontalo. Jurnal Ilmiah Agropolitan 3 (4): 293303.
Departemen Pertanian. 2002. Pendidikan dan Pelatihan Fungsioanal Penyuluh Pertanian. Deptan. Jakarta.

Ghozali, I. 2011. Model Persamaan Struktural Konsep dan Aplikasi dengan Program Amos 22.0. Badan Penerbit Universitas Diponegoro. Semarang.

Hartati P., M.Y. Surung, Sudirman, dan A. Wahab. 2011. Analisis kinerja penyuluh pertanian di Kabupaten Bantaeng Sulawesi Selatan. Jurnal agrisistem 7 (2): 95-97.

Kementerian Pertanian, 2016. Pedoman Pelaksanaan Evaluasi Kinerja Penyuluh Pertanian Dengan Sistem on Line. Pusat Penyuluhan Pertanian, Badan Penyuluhan dan Pengembangan SDM Pertanian. Kementerian Pertanian.

Kadarisman, 2013. Manajemen Pengembangan Sumberdaya manusia. PT. Rajagrafindo Persada. Depok.

Leilani, A., dan A. Jahi. 2006. Kinerja penyuluhan pertanian di beberapa Kabupaten Provinsi Jawa Barat. Jurnal Penyuluhan 2 (2): 99-106.

Maksoud, A.A. 2015. Developing a performance measurement model for agricultural extension agents an interdisciplinary approach. Journal of Accounting \& Organizational Change. 11 ( 2) : 215-246.

Mardikanto. T, 2009. Sistem Penyuluhan Pertanian. Sebelas Maret University Press, Surakarta.

Moeljono, D. 2003. Budaya Korporat dan Keunggulan Koperasi. PT. Elek Media Komputindo. Jakarta.

Mudayana, A.A. 2012. Hubungan beban kerja dengan kinerja karyawan di Rumah Sakit Nur Hidayah Bantul. Jurnal KESMAS Universitas Ahmad Dahlan 6 (1): 35-40.

Mujiburahmad, P. Mulyono dan D. Sadono. 2014. Kinerja penyuluh pertanian di Kabupaten Pidi Provinsi Aceh dalam melaksanakan tugas dan fungsi. Jurnal Penyuluhan 10 (2): 141-150. 
Muliady, T.R. 2009. Faktor-faktor yang Mempengaruhi Kinerja Penyuluh Pertanian Dan Dampaknya Pada Perilaku Petani Padi di Jawa Barat. Disertasi. Institut Pertanian Bogor. Bogor.

Prawirosentono, S dan D. Primasari, 2015. Kinerja \& Motivasi Karyawan. BPFE. Yogyakarta.

Sapar, A. Jahi, P.S. Asngari, A. Saleh, dan I.G.P. Purnaba, 2012. Kinerja penyuluh pertanian dan dampaknya pada kompetensi petani kakao di empat wilayah Sulawesi Selatan. Jurnal Penyuluhan 8 (1): 29-41.

Suparyadi, 2015. Manajemen Sumber Daya Manusia. CV. Andi Offset. Yogyakarta.

Supriani, 2014. Analisis Kinerja Penyuluh
Pertanian Di Kabupaten Majene. Tesis. Universitas Hasanudin. Makasar.

Sutrisno, E., 2010. Manajemen Sumber Daya Manusia, Prenada Media Group, Jakarta.

Sukino, 2014. Membangun Pertanian Dengan Pemberdayaan Masyarakat Tani. Pustaka Baru Press. Yogyakarta.

Tohir, W., 2015. Gagasan dan Persepsi, Memperjuangkan Petani dan Nelayan. Thafa media. Bantul.

Triasmoro, D. 2012. Pengaruh kemampuan, motivasi dan kinerja terhadap produktivitas kerja (studi kasus di Bappeda Kabupaten Kediri). Jurnal Ilmu Manajemen 1 (2): 49 - 60.

Wibowo, 2012. Manajemen Kinerja. Rajawali Pers. Jakarta. 